\title{
Allogeneic Mesenchymal Stem Cells: Agents of Immune Modulation
}

\author{
Karen English ${ }^{1}$ and Bernard P. Mahon ${ }^{2 *}$ \\ ${ }^{1}$ Transplantation Research Immunology Group, Nuffield Department of Surgical Sciences, John Radcliffe Hospital, \\ University of Oxford, Oxford, UK \\ ${ }^{2}$ Cellular Immunology Laboratory, Institute of Immunology, National University of Ireland Maynooth, Maynooth, \\ Co. Kildare, Ireland
}

\begin{abstract}
Adult mesenchymal stem cells possess a remarkably diverse array of immunosuppressive characteristics. The capacity to suppress the regular processes of allogeneic rejection, have allowed the use of tissue mismatched cells as therapeutic approaches in regenerative medicine and as agents of immune deviation. This review describes recent advances in understanding the mechanistic basis of mesenchymal stromal or stem cells (MSC) interaction with innate immunity. Particular emphasis is placed on the effect of Toll-like receptor signalling on MSC and a hypothesis that innate immune signals induce a 'licensing switch' in MSC is put forward. The mechanisms underlying MSC suppression of T cell responses and induction of regulatory populations are surveyed. Conflicting data regarding the influence of MSC on B cell function are outlined and discussed. Finally the limits to MSC mediated immune modulation are discussed with reference to the future clinical application of novel cell therapies. J. Cell. Biochem. 112: 1963-1968, 2011. (c) 2011 Wiley-Liss, Inc.
\end{abstract}

KEY WORDS: MESENCHYMAL STEM CELLS; IMMUNOLOGY; CELL THERAPY

C ell-based therapies to treat human disease are set to become clinical reality. To the fore of these novel approaches is the use of adult mesenchymal stromal or stem cells (MSC). The term 'mesenchymal stem cell' was coined by Caplan in 1991 [Caplan, 1991] to describe the rare population of bone marrow derived, plastic adherent cells discovered by Friedenstein and Petrokova [1966]. Originally these stromal cells were assumed to directly repair degenerative disease by differentiation; however, it is now appreciated that MSC also release soluble factors that act in a paracrine manner to promote repair [Caplan, 2009]. However, while MSC might be considered as trophic agents that guide the processes of tissue repair, the nature of the trophic activities remain ill defined.

The beneficial actions of MSC encompass anti-apoptotic, cytoprotective effects and the promotion of angiogenesis [Caplan, 2009] and it is the multifactorial, coordinated and targeted features of MSC that make the cell therapy approach superior to small molecule modalities. Angiogenic action is likely to be an important component of tissue repair; pericyte mediated vascular stability contributes to wound healing and tissue resident MSC may be derived from a perivascular precursor [Bianco et al., 2010], and may be intimately involved in neovascularisation of wounds and therefore regeneration.

Whilst the above features are important attributes of MSC biology, one trophic function has become the subject of intense scrutiny in the last 7 years. It is now apparent that MSC are powerful modulators of the mammalian immune response. These findings date back to studies which demonstrated that tissue mismatched (allogeneic) and even species mismatched (xenogeneic) MSC were effective cell therapies [Bartholomew et al., 2002; Grinnemo et al., 2004]. The implications were that MSC would disobey the regular rules of tissue transplantation and enjoy a degree of immune privilege, such that cell therapy could be based on allogeneic cells rather than autologous cell transplantation. This belief has important consequences as it means that MSC could be used as a commercially viable product, that was amenable to scale up and standardisation. It also implied that allogeneic MSC could be used as agents of immune deviation in conditions such as graft versus host disease (GvHD), type I diabetes or autoimmune diseases, in addition to regenerative applications for myocardial infarction or joint damage.
Grant sponsor: Science Foundation Ireland; Grant number: 09/SRC/B1794.

*Correspondence to: Bernard P. Mahon, Cellular Immunology Laboratory, Institute of Immunology, National University of Ireland Maynooth, Maynooth, Co. Kildare, Ireland. E-mail: bp.mahon@nuim.ie

Received 16 March 2011; Accepted 17 March 2011 •DOI 10.1002/jcb.23119 • (c) 2011 Wiley-Liss, Inc.

Published online 28 March 2011 in Wiley Online Library (wileyonlinelibrary.com). 
The intervening years have seen a rapid delineation of the mechanisms by which MSC modulate different aspects of both the innate and adaptive immune response. This has been accompanied by a large number of clinical trials in which allogeneic MSC have been safely deployed against a wide range of human diseases. This article will outline the immunological processes modulated by MSC, propose a model that attempts to resolve some conflicting data especially in innate immune modulation, discuss the implications for cell therapy, and finally survey those aspects of MSC biology that require further study.

\section{MSC SUPPRESSION OF INNATE IMMUNITY}

The innate immune system is a complex, rapid and effective barrier to microbes but is also a series of interlinked responses that can confound transplantation and cell therapy. These responses may be cell based, or involve serum components such as the complement system. Allogeneic human MSC and indeed some xenogeneic MSC typically avoid acute and hyperacute rejection mechanisms normally mediated through complement. Protection from this deletional process is afforded by MSC expression of factor $\mathrm{H}[\mathrm{Tu}$ et al., 2010] and other complement control proteins. However, whilst MSC are protected from complement killing they are not inert to other complement mediated activities. MSC can be recruited by the complement anaphylatoxins $\mathrm{C} 3 \mathrm{a}$ and $\mathrm{C} 5 \mathrm{a}$ [Schraufstatter et al., 2009], suggesting that signals initiated at sites of tissue damage recruit MSC protected from regular innate deletion. Protection also extends to cell mediated innate mechanisms as well; human MSC suppress the proliferation, surface receptor expression and effector functions of NK cells via prostaglandins and indoleamine dioxygenase (ID0); however, this protection is limited as MSC may be lysed under some circumstances by activated NK cells [Spaggiari et al., 2008] (Fig. 1).

An emerging concept is that MSC are not only protected from innate immune functions, but may contribute to shaping the processes of inflammation and repair. Therefore MSC are properly considered in the context of inflammatory responses. Monocytes and macrophages are frontline immune effector cells capable of destructive and lytic effects at sites of microbial insult, but can produce a range of regenerative factors involved in repair. Recent data suggest MSC may assist in coordination of these processes [Ohtaki et al., 2008; Nemeth et al., 2009]. Likewise, MSC block neutrophil function by suppressing the oxidative burst of resting and activated neutrophils while preserving their phagocytic and chemotactic functions [Raffaghello et al., 2008]. Furthermore, recent in vivo data suggest that MSC also suppress inflammatory eosinophil localisation in vivo [Kavanagh and Mahon, 2011]. Thus MSC appear to be recruited by, but protected from, the principle innate deletional mechanisms and suppress a range of inflammatory pathways consistent with functions in co-ordinating the resolution of inflammation and a transition to reparative processes.

Thus there is a conceptual dilemma in modelling MSC interaction with the innate immune response. MSC need to be recruited to sites

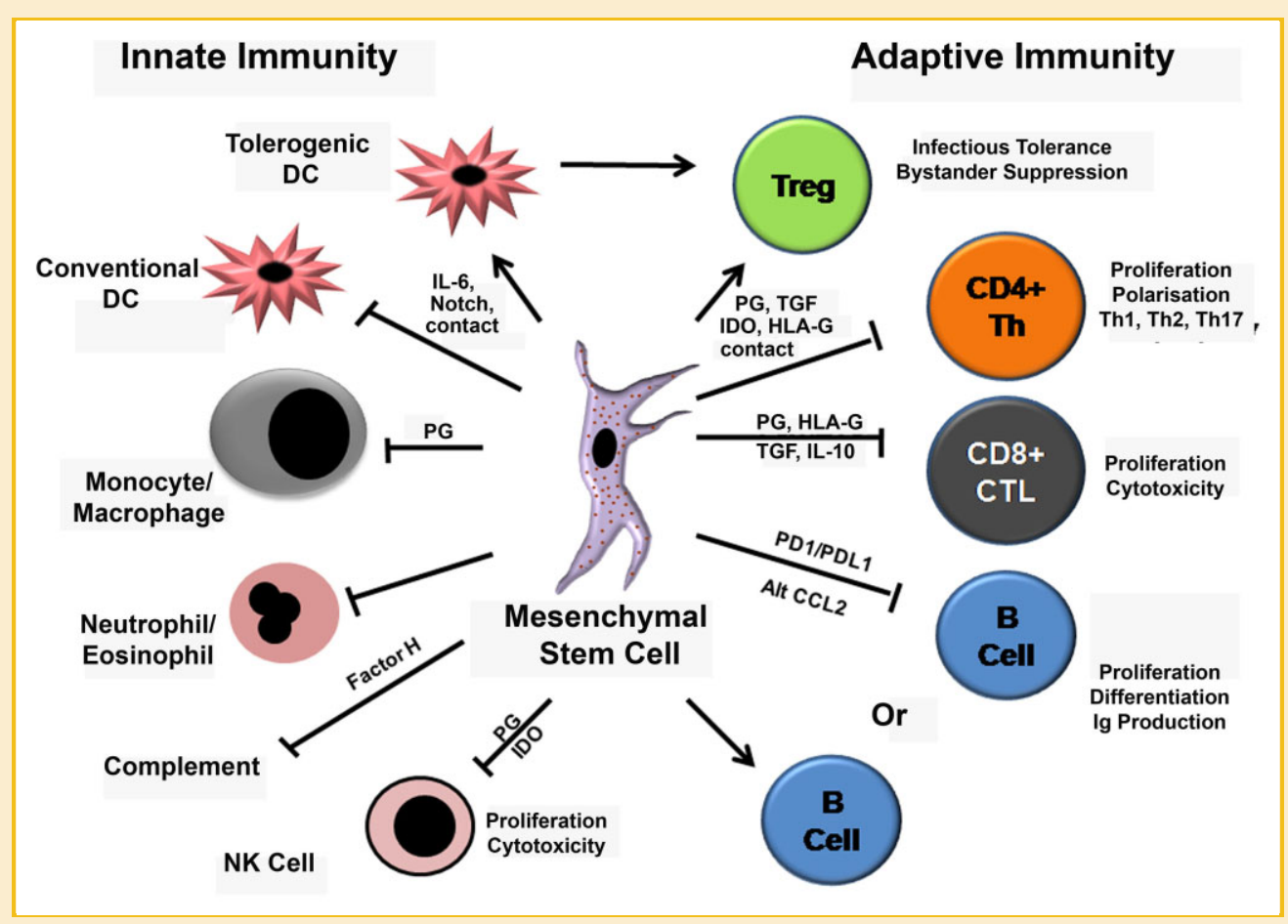

Fig. 1. Summary of MSC-immune interactions. MSC modulate innate and adaptive immunity through cell contact and soluble factors such as prostaglandins (PG), interleukins (IL)-6 and 10, Transforming growth factor (TGF)- $\beta$, and expression of the enzyme indoleamine 2,3,dioxygenase (IDO) resulting in immune suppression (blunt lines). MSC also suppress immunity by modulating DC maturation and inducing regulatory T cells (arrows). Although MSC can suppress B cell responses either directly or via CD4 ${ }^{+}$Th suppression, activation of B cells and antibody (Ig) stimulation can occur in some situations. 
of physiological insult, contribute to repair, and the resolution of inflammation, but not interfere with the processes of immune protection against pathogens. In this regard the differential expression of Toll-like receptors (TLR) and the control of expression has assumed a central importance [Pevsner-Fischer et al., 2007; Liotta et al., 2008; Tomchuck et al., 2008]. MSC express a range of TLR, and signalling via these receptors influences migration, survival, differentiation and immunosuppressive capacity. MSC immune modulation may be down-regulated by TLR3 and TLR4 ligands [Liotta et al., 2008; Romieu-Mourez et al., 2009] but enhanced by IFN- $\gamma$ [English et al., 2007]. However, TLR ligation alters the induction of cytokines and other inflammatory mediators and under some conditions, further enhances MSC mediated immune suppression [Tomchuck et al., 2008]. These findings suggest a model where inflammation in the absence of pathogen associated molecular pattern (PAMP) molecules stimulates or 'licences' MSC to promote regular (non-fibrotic) repair and dampen inflammation (Fig. 2). In contrast, in the presence of PAMPS and robust TLR signalling (e.g., tissue damage where pathogens are yet to be cleared) MSC are less suppressive of inflammation and adopt a more fibrotic character. If this hypothesis proves correct, MSC may be particularly effective in suppressing chronic inflammation associated with autoimmunity without impairing inflammatory responses essential to antimicrobial defence.

\section{MSC MODULATION OF DENDRITIC CELL FUNCTION}

Dendritic cells (DC) are sentinel cells critical for the initiation of antigen specific helper $\mathrm{T}$ cells. Host or graft derived $\mathrm{DC}$ can contribute to graft rejection through either the direct or indirect pathways of allorecognition, and MSC modulate DC development and function in multiple ways [Nauta et al., 2006; Djouad et al., 2007]. For example MSC appear to have differential effects on the generation of conventional DC and plasmacytoid DC [Chen et al., 2007]. Most importantly, MSC modulate conventional DC maturation to induce a tolerogenic DC population. This involves down modulation of DC expressions of MHC class II, the co-stimulatory molecules CD40, CD80 and CD86, and prevention of the lymph node homing chemokine receptor CCR7 [Djouad et al., 2007; English et al., 2008; Li et al., 2008; Zhang et al., 2009]. Conversely allogeneic MSC preserve DC expression of E-cadherin in vitro [English et al., 2008], implying that MSC suppress lymph node homing (a prerequisite for $\mathrm{T}$ cell response initiation) and anchor the $\mathrm{DC}$ in the peripheral tissues, a hypothesis that awaits testing in vivo. What is clear is that MSC suppress DC antigen presentation, surface marker switch, and homing capacity - the three cardinal signs of maturation.

MSC also 're-programme' the conventional myeloid DC response to activating stimuli, converting pro-inflammatory responses (IL12, TNF- $\alpha$ ) to anti-inflammatory cytokine production (IL-10) [Zhang et al., 2009]. Functionally, DC that have encountered MSC suppress the proliferation of activated T cells [Zhang et al., 2009], influence the ratio of $\mathrm{T}$ cell subsets, and promote regulatory $\mathrm{T}$ cells (Treg) [Li et al., 2008; Ge et al., 2009]. Once again it is likely that different in vivo microenvironments and the specific conditions encountered will influence the precise effect that MSC have on DC, these variables are compounded by the heterogeneity of DC populations used in such studies and these considerations may explain the heterogeneity of data reported to date. Nevertheless,

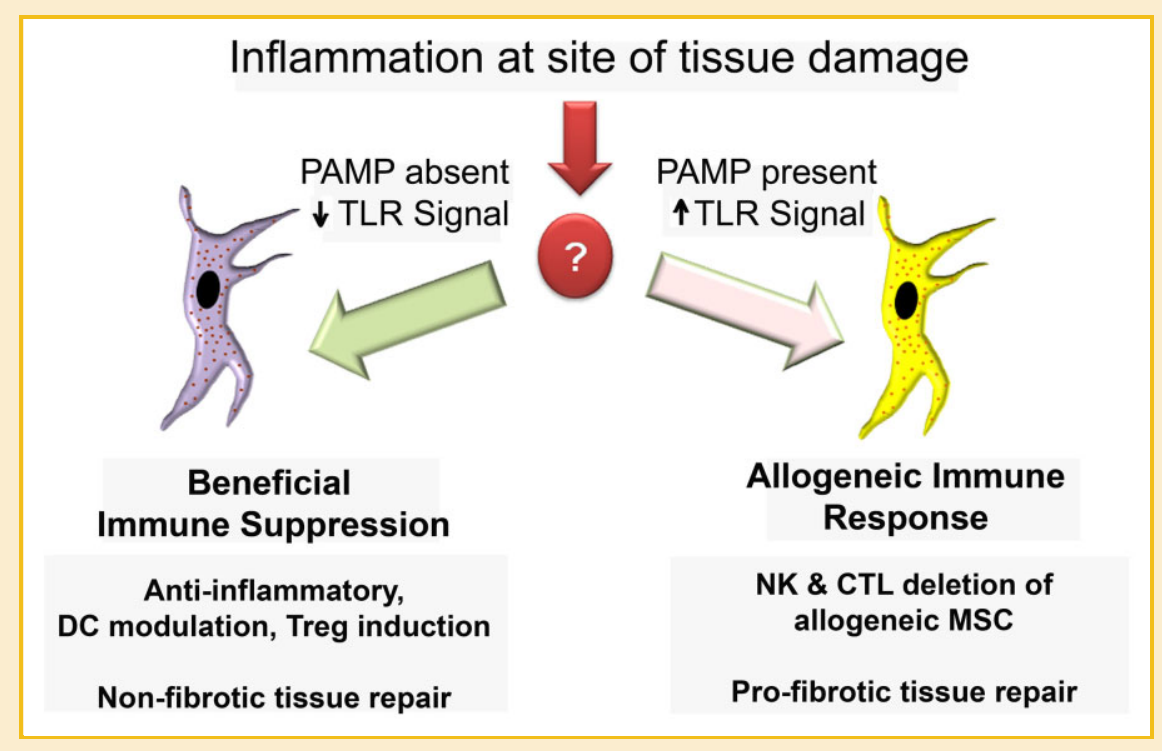

Fig. 2. A hypothetical MSC switch. Inflammatory signals are essential to recruit MSC to sites of tissue damage, causing the stimulation or 'licensing' of enhanced function. This may be influenced by the presence of pathogen associated molecular pattern molecules (PAMP) acting as a switch to activate Toll-like receptor (TLR) signalling. Under inflammatory conditions in the absence of PAMP, MSC are licensed for anti-inflammatory, anti-fibrotic and reparative functions; however when TLR are engaged (such as during active microbe driven pathology), a more fibrotic response is initiated, and MSC are less suppressive of inflammation. 
MSC clearly preserve DC immaturity, reduce the capacity for inflammatory responses and limit the capacity of DC to initiate T cell responses.

\section{MSC SUPPRESSION OF ADAPTIVE IMMUNITY}

The ability of MSC to suppress alloantigen driven proliferation in mixed lymphocyte reactions was an early indication that these cells disobey the conventional paradigm regarding adaptive immunity to non-matched cells [Bartholomew et al., 2002]. This is in part attributable to MSC production of prostaglandins [English et al., 2007; Ryan et al., 2007]. However, the capacity of MSC to modulate $\mathrm{T}$ cell responses is also dependent on the inflammatory microenvironment in which MSC and T cells interact [Polchert et al., 2008]. Unexpectedly, IFN- $\gamma$ does not break but rather enhances the capacity of MSC to suppress T cell proliferation through induction of IDO and other factors [English et al., 2007; Ryan et al., 2007; Ren et al., 2008]. Indeed some studies suggest that there is a requirement for IFN- $\gamma$, and/or IL-1 $\beta$ in the activation of MSC immune suppressive functions [Ren et al., 2008], a finding that parallels repair in non-mammalian systems where inflammation is a prerequisite for regeneration [Young, 2004].

The differentiation of $\mathrm{CD} 4+\mathrm{T}$ cells to specific subsets is also influenced by MSC; with the mesenchymal cell skewing $\mathrm{T}$ cell responses towards regulatory patterns of cytokine secretion and concurrent suppression of Th1, Th2 or Th17 responses [Nemeth et al., 2009; Rafei et al., 2009; Ghannam et al., 2010]. These data are supported by elegant in vivo models of transplantation and autoimmune disease where MSC alter $\mathrm{T}$ cell polarisation away from the typical effector responses [Casiraghi et al., 2008; Ge et al., 2009; Rafei et al., 2009; Kavanagh and Mahon, 2011]. Treg themselves are candidate cell therapeutics but the ability of MSC to induce these cells and also mediate repair suggests cell therapy directed at the induction of tolerance in organ transplantation, GvHD, and autoimmune disorders. It is well established that Treg control alloreactive $\mathrm{T}$ cell responses [Nadig et al., 2010] and that MSC can directly induce $\mathrm{CD} 4{ }^{+} \mathrm{CD} 25^{+}$FoxP $^{+}$Treg [English et al., 2009]. MSC-induced Treg have been shown to be donor specific in a mouse model of cardiac allograft rejection [Casiraghi et al., 2008], and human Treg induced by MSC can be isolated and suppress allogeneic responses even when MSC are no longer present [English et al., 2009]. Thus MSC suppression via Treg appears to operate by both infectious tolerance and bystander suppressive mechanisms [Griffin et al., 2010].

The signals involved in MSC induction of Treg have been investigated by a number of groups. While cell contact in combination with PGE2 and TGF- $\beta$ are key factors [English et al., 2009]; MSC secretion of HLA-G, IL-10 and LIF can also drive Treg expansion [Selmani et al., 2008]. The induction of Treg by allogeneic MSC has functional relevance in vivo, in a murine model of allergic asthma the beneficial therapeutic effect of MSC therapy is lost when Treg are depleted [Kavanagh and Mahon, 2011].

MSC-mediated immunomodulation occurs by multiple redundant pathways, and the induction of $\mathrm{CD}^{+}$Treg is paralleled by other modulatory mechanisms. CD8+ regulatory cells can be induced by
MSC, and MSC can inhibit effector $\mathrm{CD}^{+}$cytotoxic T lymphocyte (CTL) proliferation [Rasmusson et al., 2003; Ramasamy et al., 2008]. MSC were not lysed by CD8 ${ }^{+} \mathrm{T}$ cells [Rasmusson et al., 2003], and soluble HLA-G played a partial protective role [Morandi et al., 2008]. However, there is heterogeneity in the findings with regard to the effect of MSC on CTL killing of target cells. Rasmusson et al. [2003] showed that inhibition of CTL mediated lysis in mixed lymphocyte cultures was only effective when MSC were present at the beginning of a 6-day culture whereas addition of MSC at day 3 or in the effector cytotoxic phase had no effect on CTL function. Similarly, Ramasamy et al. [2008] found that MSC did not inhibit CTL mediated lysis of target cells in short-term assay systems. While it is difficult to compare data across different experimental systems these findings may indicate that MSC are more suppressive of CTL proliferation and/or induction (of antigen-specific responses) than the effector or lytic processes. This interpretation is consistent with the finding that MSC therapy does not interfere with virus-specific T cell responses [Karlsson et al., 2008].

Studies of the influence of MSC on B cell function have also generated heterogeneous results [Corcione et al., 2006; Rasmusson et al., 2007; Rafei et al., 2008; Traggiai et al., 2008; Asari et al., 2009]. Co-culture of human MSC with purified B cell populations under stimulatory conditions may inhibit B cell activation (proliferation differentiation, immunoglobulin (Ig) production and chemotaxis) [Corcione et al., 2006]. This suppression may be mediated by alternatively cleaved CCL2 [Rafei et al., 2008], and the PD1/PDL1 interaction [Schena et al., 2010]. In contrast, there are consistent reports of MSC mediated stimulatory effects on in vitroactivated B cells or plasma cells from healthy humans [Rasmusson et al., 2007] and in patients with systemic lupus erythematosis (SLE) [Traggiai et al., 2008]. The reasons for such apparently contradictory results cannot be fully assigned to variability in the sources of MSC, or the different antigen-dependent or polyclonal stimuli used. There appears to be a genuine, if limited, MSC mediated stimulatory phenomenon in vivo. The recent appreciation of CD4+ T follicular helper cells and new techniques to track individual MSC to lymph nodes in vivo [Steyer et al., 2009] may give some clues to the biological phenomena operating in the B cell compartment in the near future. Intriguingly it is possible that MSC are inducing the phenomenon of split tolerance with differential effects on the T cell and B cell compartments [Nash and Ashford, 1982], and systems where $\mathrm{T}$ cell-independent $\mathrm{B}$ cell responses are studied may resolve these issues.

\section{DEFINING THE LIMITS OF MSC MEDIATED SUPPRESSION}

Allogeneic MSC have now been used therapeutically and safely in a large number of human clinical trials [Griffin et al., 2010]. These diverse studies can be informative in revealing whether the immune suppressive properties of MSC are sufficient to overcome the diverse processes of immune priming, and effector responses provoked by allogeneic cells. Pre-clinical and clinical studies provide evidence for a therapeutic benefit of allogeneic MSC, however, whether MSC enjoy complete immune privilege in vivo seems less clear and this 
may impact on the clinical targets, and commercial benefits of MSC therapies in the long-term. For example, the immunogenicity of MSC following differentiation to chondrocytes, osteocytes or other lineages is poorly characterised, and may be of importance for cell therapy for myocardial, bone or joint diseases. In a rabbit model, allogeneic MSC-derived osteogenic cells retained immunosuppressive properties in vitro and functioned as osteoblasts in vivo without sensitising to a subsequent MSC-donor-specific skin graft [Liu et al., 2006]; however, recent data suggest that allogeneic MSC are immunogenic on differentiation and this limits their benefit [Huang et al., 2010]. It is also unclear whether current immunosuppressive modalities for organ transplantation influence the therapeutic effects of allogeneic MSC in vivo. The calcineurin inhibitor tacrolimus reduces anti-donor antibody responses to allogeneic MSC in a pig model [Poncelet et al., 2007]. Likewise, low-dose sirolimus combined with allogeneic MSC therapy resulted in longterm survival of MHC-mismatched heart transplants in mice [Ge et al., 2009], suggesting cell therapy will not confound conventional approaches. In many diseases, it is not known how long (or indeed where) MSC need to persist in vivo in order to exert their beneficial effects. For clinical applications that require permanent MSC engraftment, even weak immunogenicity may confound successful translation [Huang et al., 2010]. However, in conditions where allogeneic MSC are used as agents of immune deviation to counter an acute inflammatory condition or to 're-program' autoimmunity, then persistence may be less important and the suppressive features of MSC may be sufficient to allow standardised allogeneic cell therapy.

\section{CONCLUDING REMARKS}

The last decade has seen a remarkable shift in our appreciation of the potential uses for MSC. First MSC were recognised as having immunosuppressive properties, then the trophic (as opposed to regenerative) effects became clear. These advances were followed by a rapid delineation of the multiple pathways by which MSC modulate immunity and somewhat unrealistic ambitions that MSC were an immunological panacea. The field is now defining the limits of cell therapy and the correlates of efficacy. The very many ongoing clinical trials of allogeneic MSC and MSC like cells [Griffin et al., 2010] suggest that cell therapy for currently intractable conditions is a realistic prospect. However, a number of issues remain to be resolved such as the hierarchy of the immune suppressive functions of MSC and the degree of redundancy that exists among the many suppressive processes that have been identified to date. The limits of immune modulation by allogeneic MSC are becoming clear, and these limits will influence the choice of targets for cell therapy and help shape the next generation of genetically modified or enhanced allogeneic MSC.

\section{ACKNOWLEDGMENTS}

This material is based upon works supported by the Science Foundation Ireland under grant no. 09/SRC/B1794. Karen English is supported by a Marie Curie Intra-European Fellowship for Career Development.

\section{REFERENCES}

Asari S, Itakura S, Ferreri K, Liu CP, Kuroda Y, Kandeel F, Mullen Y. 2009. Mesenchymal stem cells suppress B-cell terminal differentiation. Exp Hematol 37(5):604-615.

Bartholomew A, Sturgeon C, Siatskas M, Ferrer K, McIntosh K, Patil S, Hardy W, Devine S, Ucker D, Deans R, Moseley A, Hoffman R. 2002. Mesenchymal stem cells suppress lymphocyte proliferation in vitro and prolong skin graft survival in vivo. Exp Hematol 30(1):42-48.

Bianco P, Robey PG, Saggio I, Riminucci M. 2010. "Mesenchymal” stem cells in human bone marrow (skeletal stem cells): A critical discussion of their nature, identity, and significance in incurable skeletal disease. Hum Gene Ther 21(9):1057-1066.

Caplan AI. 1991. Mesenchymal stem cells. J Orthop Res 9(5):641-650.

Caplan AI. 2009. Why are MSCs therapeutic? New data: New insight. J Pathol 217(2):318-324.

Casiraghi F, Azzollini N, Cassis P, Imberti B, Morigi M, Cugini D, Cavinato RA, Todeschini M, Solini S, Sonzogni A, Perico N, Remuzzi G, Noris M. 2008. Pretransplant infusion of mesenchymal stem cells prolongs the survival of a semiallogeneic heart transplant through the generation of regulatory $\mathrm{T}$ cells. J Immunol 181(6):3933-3946.

Chen L, Zhang W, Yue H, Han Q, Chen B, Shi M, Li J, Li B, You S, Shi Y, Zhao RC. 2007. Effects of human mesenchymal stem cells on the differentiation of dendritic cells from CD34+ cells. Stem Cells Dev 16(5):719-731.

Corcione A, Benvenuto F, Ferretti E, Giunti D, Cappiello V, Cazzanti F, Risso M, Gualandi F, Mancardi GL, Pistoia V, Uccelli A. 2006. Human mesenchymal stem cells modulate B-cell functions. Blood 107(1):367-372.

Djouad F, Charbonnier LM, Bouffi C, Louis-Plence P, Bony C, Apparailly F, Cantos C, Jorgensen C, Noel D. 2007. Mesenchymal stem cells inhibit the differentiation of dendritic cells through an interleukin-6-dependent mechanism. Stem Cells 25(8):2025-2032.

English K, Barry FP, Field-Corbett CP, Mahon BP. 2007. IFN-gamma and TNF-alpha differentially regulate immunomodulation by murine mesenchymal stem cells. Immunol Lett 110(2):91-100.

English K, Barry FP, Mahon BP. 2008. Murine mesenchymal stem cells suppress dendritic cell migration, maturation and antigen presentation. Immunol Lett 115(1):50-58.

English K, Ryan JM, Tobin L, Murphy MJ, Barry FP, Mahon BP. 2009. Cell contact, prostaglandin $\mathrm{E}(2)$ and transforming growth factor beta 1 play nonredundant roles in human mesenchymal stem cell induction of CD4+CD25(High) forkhead box P3+ regulatory T cells. Clin Exp Immunol 156(1):149-160.

Friedenstein AJP, Petrokova KV. 1966. Osteogenesis in transplants of bone marrow cells. J Embryol Exp Morphol 16:381-390.

Ge W, Jiang J, Baroja ML, Arp J, Zassoko R, Liu W, Bartholomew A, Garcia B, Wang H. 2009. Infusion of mesenchymal stem cells and rapamycin synergize to attenuate alloimmune responses and promote cardiac allograft tolerance. Am J Transplant 9(8):1760-1772.

Ghannam S, Pene J, Torcy-Moquet G, Jorgensen C, Yssel H. 2010. Mesenchymal stem cells inhibit human Th17 cell differentiation and function and induce a T regulatory cell phenotype. J Immunol 185(1):302-312.

Griffin MD, Ritter T, Mahon BP. 2010. Immunological aspects of allogeneic mesenchymal stem cell therapies. Hum Gene Ther 21(12):1641-1655.

Grinnemo KH, Mansson A, Dellgren G, Klingberg D, Wardell E, Drvota V, Tammik C, Holgersson J, Ringden 0, Sylven C, Le Blanc K. 2004. Xenoreactivity and engraftment of human mesenchymal stem cells transplanted into infarcted rat myocardium. J Thorac Cardiovasc Surg 127(5):1293-1300.

Huang XP, Sun Z, Miyagi Y, McDonald Kinkaid H, Zhang L, Weisel RD, Li RK. 2010. Differentiation of allogeneic mesenchymal stem cells induces immunogenicity and limits their long-term benefits for myocardial repair. Circulation 122(23):2419-2429. 
Karlsson H, Samarasinghe S, Ball LM, Sundberg B, Lankester AC, Dazzi F, Uzunel M, Rao K, Veys P, Le Blanc K, Ringden 0, Amrolia PJ. 2008. Mesenchymal stem cells exert differential effects on alloantigen and virus-specific T-cell responses. Blood 112(3):532-541.

Kavanagh H, Mahon BP. 2011. Allogeneic mesenchymal stem cells prevent allergic airway inflammation by inducing murine regulatory T cells. Allergy 66:523-531.

Li H, Guo Z, Jiang X, Zhu H, Li X, Mao N. 2008. Mesenchymal stem cells alter migratory property of $\mathrm{T}$ and dendritic cells to delay the development of murine lethal acute graft-versus-host disease. Stem Cells 26(10):2531-2541.

Liotta F, Angeli R, Cosmi L, Fili L, Manuelli C, Frosali F, Mazzinghi B, Maggi L, Pasini A, Lisi V, Santarlasci V, Consoloni L, Angelotti ML, Romagnani P, Parronchi P, Krampera M, Maggi E, Romagnani S, Annunziato F. 2008. Tolllike receptors 3 and 4 are expressed by human bone marrow-derived mesenchymal stem cells and can inhibit their T-cell modulatory activity by impairing Notch signaling. Stem Cells 26(1):279-289.

Liu H, Kemeny DM, Heng BC, Ouyang HW, Melendez AJ, Cao T. 2006. The immunogenicity and immunomodulatory function of osteogenic cells differentiated from mesenchymal stem cells. J Immunol 176(5):2864-2871.

Morandi F, Raffaghello L, Bianchi G, Meloni F, Salis A, Millo E, Ferrone S, Barnaba V, Pistoia V. 2008. Immunogenicity of human mesenchymal stem cells in HLA-class I-restricted T-cell responses against viral or tumorassociated antigens. Stem Cells 26(5):1275-1287.

Nadig SN, Wieckiewicz J, Wu DC, Warnecke G, Zhang W, Luo S, Schiopu A, Taggart DP, Wood KJ. 2010. In vivo prevention of transplant arteriosclerosis by ex vivo-expanded human regulatory T cells. Nat Med 16(7):809-813.

Nash AA, Ashford NP. 1982. Split T-cell tolerance in herpes simplex virusinfected mice and its implication for anti-viral immunity. Immunology 45(4):761-767.

Nauta AJ, Kruisselbrink AB, Lurvink E, Willemze R, Fibbe WE. 2006. Mesenchymal stem cells inhibit generation and function of both CD34+derived and monocyte-derived dendritic cells. J Immunol 177(4):2080-2087.

Nemeth K, Leelahavanichkul A, Yuen PS, Mayer B, Parmelee A, Doi K, Robey PG, Leelahavanichkul K, Koller BH, Brown JM, Hu X, Jelinek I, Star RA, Mezey E. 2009. Bone marrow stromal cells attenuate sepsis via prostaglandin E(2)-dependent reprogramming of host macrophages to increase their interleukin-10 production. Nat Med 15(1):42-49.

Ohtaki H, Ylostalo JH, Foraker JE, Robinson AP, Reger RL, Shioda S, Prockop DJ. 2008. Stem/progenitor cells from bone marrow decrease neuronal death in global ischemia by modulation of inflammatory/immune responses. Proc Natl Acad Sci USA 105(38):14638-14643.

Pevsner-Fischer M, Morad V, Cohen-Sfady M, Rousso-Noori L, ZaninZhorov A, Cohen S, Cohen IR, Zipori D. 2007. Toll-like receptors and their ligands control mesenchymal stem cell functions. Blood 109(4):1422-1432.

Polchert D, Sobinsky J, Douglas G, Kidd M, Moadsiri A, Reina E, Genrich K, Mehrotra S, Setty S, Smith B, Bartholomew A. 2008. IFN-gamma activation of mesenchymal stem cells for treatment and prevention of graft versus host disease. Eur J Immunol 38(6):1745-1755.

Poncelet AJ, Vercruysse J, Saliez A, Gianello P. 2007. Although pig allogeneic mesenchymal stem cells are not immunogenic in vitro, intracardiac injection elicits an immune response in vivo. Transplantation 83(6):783-790.

Rafei M, Hsieh J, Fortier S, Li M, Yuan S, Birman E, Forner K, Boivin MN, Doody K, Tremblay M, Annabi B, Galipeau J. 2008. Mesenchymal stromal cell-derived CCL2 suppresses plasma cell immunoglobulin production via STAT3 inactivation and PAX5 induction. Blood 112(13):4991-4998.

Rafei M, Campeau PM, Aguilar-Mahecha A, Buchanan M, Williams P, Birman E, Yuan S, Young YK, Boivin MN, Forner K, Basik M, Galipeau J. 2009. Mesenchymal stromal cells ameliorate experimental autoimmune encephalomyelitis by inhibiting CD4 Th17 T cells in a CC chemokine ligand 2dependent manner. J Immunol 182(10):5994-6002.
Raffaghello L, Bianchi G, Bertolotto M, Montecucco F, Busca A, Dallegri F, Ottonello L, Pistoia V. 2008. Human mesenchymal stem cells inhibit neutrophil apoptosis: A model for neutrophil preservation in the bone marrow niche. Stem Cells 26(1):151-162.

Ramasamy R, Tong CK, Seow HF, Vidyadaran S, Dazzi F. 2008. The immunosuppressive effects of human bone marrow-derived mesenchymal stem cells target $\mathrm{T}$ cell proliferation but not its effector function. Cell Immunol 251(2):131-136.

Rasmusson I, Ringden 0, Sundberg B, Le Blanc K. 2003. Mesenchymal stem cells inhibit the formation of cytotoxic T lymphocytes, but not activated cytotoxic $\mathrm{T}$ lymphocytes or natural killer cells. Transplantation 76(8):1208-1213.

Rasmusson I, Le Blanc K, Sundberg B, Ringden 0. 2007. Mesenchymal stem cells stimulate antibody secretion in human B cells. Scand J Immunol 65(4):336-343.

Ren G, Zhang L, Zhao X, Xu G, Zhang Y, Roberts AI, Zhao RC, Shi Y. 2008. Mesenchymal stem cell-mediated immunosuppression occurs via concerted action of chemokines and nitric oxide. Cell Stem Cell 2(2):141-150.

Romieu-Mourez R, Francois M, Boivin MN, Bouchentouf M, Spaner DE, Galipeau J. 2009. Cytokine modulation of TLR expression and activation in mesenchymal stromal cells leads to a proinflammatory phenotype. J Immunol 182(12):7963-7973.

Ryan JM, Barry F, Murphy JM, Mahon BP. 2007. Interferon-gamma does not break, but promotes the immunosuppressive capacity of adult human mesenchymal stem cells. Clin Exp Immunol 149(2):353-363.

Schena F, Gambini C, Gregorio A, Mosconi M, Reverberi D, Gattorno M, Casazza S, Uccelli A, Moretta L, Martini A, Traggiai E. 2010. IFN-gamma dependent inhibition of $\mathrm{B}$ cell activation by bone marrow derived mesenchymal stem cells in a murine model of systemic lupus erythematosus. Arthritis Rheum 62(9):2776-2786.

Schraufstatter IU, Discipio RG, Zhao M, Khaldoyanidi SK. 2009. C3a and C5a are chemotactic factors for human mesenchymal stem cells, which cause prolonged ERK1/2 phosphorylation. J Immunol 182(6):3827-3836.

Selmani Z, Naji A, Zidi I, Favier B, Gaiffe E, Obert L, Borg C, Saas P, Tiberghien P, Rouas-Freiss N, Carosella ED, Deschaseaux F. 2008. Human leukocyte antigen-G5 secretion by human mesenchymal stem cells is required to suppress $\mathrm{T}$ lymphocyte and natural killer function and to induce CD4+CD25highFOXP3+ regulatory T cells. Stem Cells 26(1):212-222.

Spaggiari GM, Capobianco A, Abdelrazik H, Becchetti F, Mingari MC, Moretta L. 2008. Mesenchymal stem cells inhibit natural killer-cell proliferation, cytotoxicity, and cytokine production: Role of indoleamine 2,3dioxygenase and prostaglandin E2. Blood 111(3):1327-1333.

Steyer GJ, Roy D, Salvado 0, Stone ME, Wilson DL. 2009. Cryo-imaging of fluorescently-labeled single cells in a mouse. Proc Soc Photo Opt Instrum Eng 7262:72620W-72620W8. http://www.ncbi.nlm.nih.gov/pmc/articles/ PMC2743343/pdf/nihms-112388.pdf

Tomchuck SL, Zwezdaryk KJ, Coffelt SB, Waterman RS, Danka ES, Scandurro AB. 2008. Toll-like receptors on human mesenchymal stem cells drive their migration and immunomodulating responses. Stem Cells 26(1):99-107.

Traggiai E, Volpi S, Schena F, Gattorno M, Ferlito F, Moretta L, Martini A. 2008. Bone marrow-derived mesenchymal stem cells induce both polyclonal expansion and differentiation of B cells isolated from healthy donors and systemic lupus erythematosus patients. Stem Cells 26(2):562-569.

Tu Z, Li Q, Bu H, Lin F. 2010. Mesenchymal stem cells inhibit complement activation by secreting factor H. Stem Cells Dev 19(11):1803-1809.

Young HE. 2004. Existence of reserve quiescent stem cells in adults, from amphibians to humans. Curr Top Microbiol Immunol 280:71-109.

Zhang B, Liu R, Shi D, Liu X, Chen Y, Dou X, Zhu X, Lu C, Liang W, Liao L, Zenke M, Zhao RC. 2009. Mesenchymal stem cells induce mature dendritic cells into a novel Jagged-2-dependent regulatory dendritic cell population. Blood 113(1):46-57. 